\title{
Indoor Air Quality and Perceived Health Effects Experienced by Occupants of an Office Complex in a Typical Tertiary Institution in Nigeria
}

\author{
Morakinyo Oyewale Mayowa*, Ana Godson Rowland, Hammed Taiwo Babatunde, \\ Adejumo Mumuni \\ Department of Environmental Health Sciences, Faculty of Public Health, College of Medicine, University of Ibadan, Ibadan, Nigeria
}

Email address:

wahlemirax@gmail.com (O. M. Morakinyo), anagrow@yahoo.com (G. R. Ana), hammetab2003@yahoo.co.uk (T. B. Hammed), adejumo_mumni@yahoo.com (M. Adejumo)

\section{To cite this article:}

Morakinyo Oyewale Mayowa, Ana Godson Rowland, Hammed Taiwo Babatunde, Adejumo Mumuni. Indoor Air Quality and Perceived Health Effects Experienced by Occupants of an Office Complex in a Typical Tertiary Institution in Nigeria. Science Journal of Public Health . Vol. 3, No. 4, 2015, pp. 552-558. doi: 10.11648/j.sjph.20150304.24

\begin{abstract}
Exposure to compromised indoor air is one of the factors affecting the health and productivity of workers in the workplace. Studies have proved that the number of related health complaints from workplace has increased in recent years. Indoor air quality and perceived health effects experienced by occupants of selected offices and classrooms in the Oladele Ajose Building (OAJB) were assessed in this study. Temperature and Relative Humidity (RH) of seven indoor locations within OAJB were monitored using Multi-Tester N21FR during the dry season. Values obtained for temperature and RH were compared with the American Society of Heating, Refrigerating and Air-Conditioning Engineers (ASHRAE) guideline limits for indoor environment of $23.5-25.5^{\circ} \mathrm{C}$ and $30-50 \%$ respectively. Airborne Total Bacteria Count (TBC) and Total Fungi Count (TFC) were determined using Polish Standard PN 89/Z-04008/08 and values obtained compared with the American Industrial Hygiene Association (AIHA) guideline limit of $500 \mathrm{cfu} / \mathrm{m}^{3}$ for total airborne microbial count in an indoor environment. A semi-structured questionnaire was used to elicit information from staff and students. Data collected were analysed using descriptive statistics. Mean indoor temperature and $\mathrm{RH}$ in the morning were $30.3 \pm 2.5{ }^{\circ} \mathrm{C}$ and $30.5 \pm 2.1 \%$ respectively and $66.5 \pm 5.6^{\circ} \mathrm{C}$ and $66.6 \pm 5.6 \%$ respectively in the afternoon. The TBC and TFC were lower than guideline limit. Bacterial species isolated included Bacillus, Staphylococcus, Micrococcus, Pseudomonas and Proteus while fungi specie includes Aspergillus. Mean age of respondents was $31.4 \pm 8.9$ years. Reported symptoms in the last six months prior the study include cough $(65.5 \%)$, fatigue $(81.0 \%)$ and wheezing $(87.9 \%)$. Temperature and RH of the sampled locations were higher than acceptable limits. These together with the airborne microbes may influence the prevalence of health symptoms experienced by respondents. Routine air monitoring of office buildings should be carried out to ensure conformance with stipulated guidelines.
\end{abstract}

Keywords: Indoor Air Quality, Perceived Health Effects, Workplace, Ibadan

\section{Introduction}

Indoor environments are fundamental environmental factors capable of impacting health $[1,2]$. The quality of air in homes, offices, schools, day care centres, public buildings, health care facilities and other private and public buildings where people spend over $80 \%(3 / 5)$ of their time daily is crucial for healthy living and people's well-being [3]. Air quality of indoor environments is one of the main factors affecting the health, well-being and productivity of people. The effect on health rises as exposure to and density of air pollution increases $[4,5,6]$.

Indoor air contains a complex mixture of bioaerosols such as fungi, bacteria and allergens along with non-biological particles [7]. Bioaersosols contribute to about 5 to $34 \%$ of indoor air pollution [8]. Sources of indoor bioaerosols are often located outdoors and particles are transferred to the inside through openings of the building envelope (windows, doors).

Evidence from workplaces depicts various environmental conditions that are closely associated with the incidence of measurable adverse health effects that is rapidly emerging. The number of related complaints has increased in recent years with increased building compactness, the growing use 
of synthetic materials, and energy conservation measures that reduce the amount of outside air supply [9]. Modern office equipment (e.g., photocopiers, laser printers, computers etc.), cleaning products, and outdoor air pollution can also increase the level of indoor air contamination. The reactions to these contaminants have led to the phenomenon of sick building syndrome (SBS) [9]. Previous studies has shown that there is a productivity loss of $6-10$ percent in Sick buildings $[10,11]$ due to unhealthy IAQ.

Studies on the indoor air quality of office buildings in Nigeria have not been extensively carried out. Therefore, this study was designed to determine the indoor air quality and perceived health effects experienced by occupants of an office complex in a typical tertiary institution in Ibadan, Nigeria.

\section{Materials and Methods}

\subsection{Study Area}

The study was carried out in the Oladele Ajose building of Faculty of Public Health, University of Ibadan, Nigeria. The building commissioned over two decades ago is divided into the new and old complexes. It is located at about $200 \mathrm{~m}$ from the main gate of the University College Hospital. The new building complex is made up of 3 floors with more than 50 offices asides classrooms, laboratories, library and computer rooms, and is currently being used by 5 Departments.

Ibadan where the study was conducted has a tropical wet and dry climate. Ibadan's wet season runs from March through October. November to February forms the city's dry season, during which Ibadan experiences the typical West African harmattan. The mean total rainfall for Ibadan is 1420 $\mathrm{mm}$, falling in approximately 109 days. The mean maximum temperature is $26.5^{\circ} \mathrm{C}$, minimum $21.4^{\circ} \mathrm{C}$ and the relative humidity is $74.6 \%$.

\subsection{Selection of Offices and Classrooms}

Seven locations within the Oladele Ajose building (OAJB) were selected by stratified sampling for environmental monitoring. The seven locations selected are presented in table 1 .

Table 1. Selected locations for meteorological and microbial sampling.

\begin{tabular}{ll}
\hline Location & Description \\
\hline ESL & Environmental Health Sciences' Laboratory \\
ESM & Environmental Health Sciences' main office \\
ALL & Adetokunbo Lucas' Library \\
ESR & Environmental Health Sciences' Lecture room \\
CMC & Community Medicine's classroom \\
HPC & Health Promotion and Education computer room \\
EMS & Epidemiology and Medical Statistics'office \\
\hline
\end{tabular}

\subsection{Determination of Meteorological Parameters}

A multi-tester meteorological meter, Model N21FR was used to measure the temperature $\left({ }^{\circ} \mathrm{C}\right)$ and relative humidity (\%) conditions of the selected locations between 8 a.m. and 10 a.m. in the morning and 2 a.m. and 4 p.m. in the afternoon.
The values obtained for temperature and relative humidity were compared with the American Society of Heating, Refrigerating and Air-Conditioning Engineers (ASHRAE) guideline limits of $23.5-25.5^{\circ} \mathrm{C}$ and $30-50 \%$ for indoor environment [12].

\subsection{Measurement of Indoor Air Quality}

Air samples for culturable microorganisms were collected using a gravitational method for a sampling duration of 10 min during the dry season. The microbiological agents were trapped by exposing Petri plates filled with sterile Nutrient and Potato Dextrose agar at the selected locations for a period of 4 minutes at a height of $1.5 \mathrm{~m}$ at the centre of the office. Incubation period and temperature conditions for bacteria and fungi were 2 days at $37^{\circ} \mathrm{C}$ and 4 to 7 days at $25^{\circ} \mathrm{C}$ respectively.

The total number of aerobic bacteria and fungi in the selected rooms was determined according to Polish Standard PN 89/Z-04008/08 [13]. The number of colony forming units (cfu) per plate was converted to colony forming units per cubic metre $\left(\mathrm{cfu} / \mathrm{m}^{3}\right)$. Number of microorganisms expressed as $\mathrm{cfu} / \mathrm{m}^{3}$ was estimated according to the equation and compared with the American Industrial Hygiene Association (AIHA) guideline limit of $500 \mathrm{cfu} / \mathrm{m}^{3}$ for total airborne microbial count in an indoor environment:

$$
\mathrm{Cfu} / \mathrm{m}^{3}=\mathrm{a} * 10,000 / \mathrm{p} * \mathrm{t} * 0.2
$$

Where $\mathrm{a}=$ the number of colonies on the petri plate,

$\mathrm{P}=$ the surface of the Petri plate (cubic metre) and $\mathrm{t}$ is the time of Petri exposure (seconds).

Bacterial identification was based primarily on morphology, Gram staining, growth characteristic, culture characteristics and biochemical tests. Some commonly found bacteria were identified to the genus level by comparing with Bergey's manual of systematic bacteriology [14]. Light microscope was used to determine the colony features and the morphological structures of the fungi.

\subsection{Survey and Data Analysis}

A semi-structured self-administered questionnaire that included questions on socio-demographic information, environmental condition of offices and classrooms, knowledge of IAQ and perceived health effects associated with exposure to IAQ was used to elicit information from staff (academic and non-academic) and students. Data collected was analysed using SPSS version 16. Data were summarized using mean and standard deviation (SD) for continuous variables and frequencies and percentages for categorical variables.

\section{Results}

\subsection{Meteorological Conditions}

The morning and afternoon meteorological readings (temperature and relative humidity) for the sampled rooms is presented in Table 2. The mean morning and afternoon 
indoor air temperature $\left({ }^{\circ} \mathrm{C}\right)$ of the sampled locations were $30.3 \pm 2.5$ and $30.5 \pm 2.1$ respectively while the mean relative humidity (\%) for morning and afternoon were $66.5 \pm 5.6$ and $66.6 \pm 5.6$ respectively. The morning and afternoon readings for both temperature and relative humidity in all sampled locations exceeded the ASHRAE guideline limits.

The total bacteria and total fungi counts in the selected locations in Table 3 revealed that the microbial population though present were below American Industrial Hygiene
Association (AIHA) standards. The TBC in the morning was highest at the classroom at the basement of the building and highest at Lucas' Library in the afternoon. The level of TFC in the morning was highest at the laboratory and the basement classroom whereas in the afternoon, it was highest at the Lucas' Library. Bacterial species isolated from the sample locations included Bacillus, Staphylococcus, Micrococcus, Pseudomonas and Proteus while the isolated fungi specie Aspergillus (Table 4).

Table 2. Temperature and Relative Humidity of selected sampled rooms.

\begin{tabular}{lllll}
\hline Sampled locations & Parameter & Morning & Afternoon & *ASHARE \\
\hline \multirow{2}{*}{ ESL } & $\mathrm{T}\left({ }^{\circ} \mathrm{C}\right)$ & $33.3 \pm 3.2$ & $32.2 \pm 2.3$ & $23.5-25.5$ \\
& $\mathrm{RH}(\%)$ & $66.5 \pm 5.1$ & $68.5 \pm 5.1$ & $30.0-50.0$ \\
ESM & $\mathrm{T}\left({ }^{\circ} \mathrm{C}\right)$ & $29.8 \pm 3.3$ & $31.1 \pm 6.3$ & $23.5-25.5$ \\
& $\mathrm{RH}(\%)$ & $65.1 \pm 5.4$ & $67.9 \pm 5.4$ & $30.0-50.0$ \\
$\mathrm{ALL}$ & $\mathrm{T}\left({ }^{\circ} \mathrm{C}\right)$ & $31.8 \pm 7.1$ & $31.7 \pm 2.3$ & $23.5-25.5$ \\
& $\mathrm{RH}(\%)$ & $54.1 \pm 3.3$ & $52.6 \pm 2.5$ & $30.0-50.0$ \\
ESR & $\mathrm{T}\left({ }^{\circ} \mathrm{C}\right)$ & $28.1 \pm 2.4$ & $28.3 \pm 2.2$ & $23.5-25.5$ \\
& $\mathrm{RH}(\%)$ & $69.7 \pm 5.3$ & $68.5 \pm 7.2$ & $30.0-50.0$ \\
$\mathrm{CMC}$ & $\mathrm{T}\left({ }^{\circ} \mathrm{C}\right)$ & $29.4 \pm 0.6$ & $29.3 \pm 0.6$ & $23.5-25.5$ \\
& $\mathrm{RH}(\%)$ & $70.3 \pm 7.1$ & $69.1 \pm 5.9$ & $30.0-50.0$ \\
$\mathrm{HPC}$ & $\mathrm{T}\left({ }^{\circ} \mathrm{C}\right)$ & $30.0 \pm 0.8$ & $31.3 \pm 0.8$ & $23.5-25.5$ \\
& $\mathrm{RH}(\%)$ & $70.4 \pm 6.0$ & $70.8 \pm 6.1$ & $30.0-50.0$ \\
EMS & $\mathrm{T}\left({ }^{\circ} \mathrm{C}\right)$ & $29.6 \pm 0.4$ & $30.0 \pm 0.5$ & $23.5-25.5$ \\
& $\mathrm{RH}(\%)$ & $69.5 \pm 6.0$ & $68.5 \pm 7.1$ & $30.0-50.0$ \\
\hline
\end{tabular}

*T - Temperature, *RH - Relative Humidity, *ASHARE - American Society of Heating, Refrigerating and Air-Conditioning Engineers, ESL - Environmental Health Sciences' Laboratory, ESM - Environmental Health Sciences' main office, ALL - Adetokunbo Lucas' Library, ESR - Environmental Health Sciences' Lecture room, CMC - Community Medicine's classroom, HPC - Health Promotion and Education's computer room, EMS - Epidemiology and Medical Statistics' office

Table 3. TBC and TFC of the sampled locations.

\begin{tabular}{|c|c|c|c|c|}
\hline Selected locations & Time of sampling & Total Bacteria Count $\left(\mathrm{cfu} / \mathrm{m}^{3}\right)$ & Total Fungi Count $\left(\mathrm{cfu} / \mathrm{m}^{3}\right)$ & AIHA limit \\
\hline \multirow{2}{*}{ ESL } & Morning & $0.1 \times 10^{2}$ & $0.48 \times 10^{2}$ & $5.0 \times 10^{2}$ \\
\hline & Afternoon & $0.25 \times 10^{2}$ & $0.55 \times 10^{2}$ & $5.0 \times 10^{2}$ \\
\hline ESM & Morning & $0.02 \times 10^{2}$ & $0.04 \times 10^{2}$ & $5.0 \times 10^{2}$ \\
\hline \multirow{2}{*}{ ALL } & Morning & $0.48 \times 10^{2}$ & $0.30 \times 10^{2}$ & $5.0 \times 10^{2}$ \\
\hline & Afternoon & $0.84 \times 10^{2}$ & $0.55 \times 10^{2}$ & $5.0 \times 10^{2}$ \\
\hline ESR & Morning & $0.82 \times 10^{2}$ & $0.48 \times 10^{2}$ & $5.0 \times 10^{2}$ \\
\hline \multirow{2}{*}{$\mathrm{CMC}$} & Morning & $0.46 \times 10^{2}$ & $0.37 \times 10^{2}$ & $5.0 \times 10^{2}$ \\
\hline & Afternoon & $0.72 \times 10^{2}$ & $0.45 \times 10^{2}$ & $5.0 \times 10^{2}$ \\
\hline \multirow{2}{*}{ HPC } & Morning & $0.52 \times 10^{2}$ & $0.25 \times 10^{2}$ & $5.0 \times 10^{2}$ \\
\hline & Afternoon & $0.70 \times 10^{2}$ & $0.35 \times 10^{2}$ & $5.0 \times 10^{2}$ \\
\hline \multirow{2}{*}{ EMS } & Morning & $0.48 \times 10^{2}$ & $0.12 \times 10^{2}$ & $5.0 \times 10^{2}$ \\
\hline & Afternoon & $0.70 \times 10^{2}$ & $0.16 \times 10^{2}$ & $5.0 \times 10^{2}$ \\
\hline
\end{tabular}

ESL - Environmental Health Sciences' Laboratory, ESM - Environmental Health Sciences' main office, ALL - Adetokunbo Lucas' Library, ESR Environmental Health Sciences' Lecture room, CMC - Community Medicine's classroom, HPC - Health Promotion and Education computer room, EMS Epidemiology and Medical Statistics' office

Table 4. Profile of airborne microorganisms isolated from sampled locations.

\begin{tabular}{lll}
\hline Sampled rooms & Morning & Afternoon \\
\hline ESL & Bacillus, Staphylococcus, Micrococcus, Pseudomonas, Aspergillus & Bacillus, Staphylococcus Pseudomonas, Aspergillus \\
ESM & Bacillus, Staphylococcus, Micrococcus & Bacillus, Staphylococcus \\
ALL & Micrococcus, Proteus, Bacillus & Micrococcus, Proteus, Bacillus \\
ESR & Pseudomonas, Proteus, Bacillus & Pseudomonas \\
CMC & Bacillus, Staphylococcus, Proteus, Bacillus & Bacillus, Staphylococcus \\
HPC & Micrococcus, & Micrococcus \\
EMS & Pseudomonas & Pseudomonas \\
\hline
\end{tabular}

ESL - Environmental Health Sciences' Laboratory, ESM - Environmental Health Sciences' main office, ALL - Adetokunbo Lucas' Library, ESR Environmental Health Sciences' Lecture room, CMC - Community Medicine's classroom, HPC - Health Promotion and Education computer room, EMS Epidemiology and Medical Statistics' office 


\subsection{Survey}

A total of 174 respondents were recruited with a mean age of $31.4 \pm 8.9$ years (range 23 - 59 years). There were $51.7 \%$ males and $48.3 \%$ ) females. Five percent had primary education while $79.0 \%$ had tertiary education. Majority $(75.9 \%)$ were students as compared to $6.9 \%$ and $17.2 \%$ that were teaching and non-teaching staff respectively (Table 5). About $60.0 \%$ spent more than 8 hours per day in their offices and classroom environment.

Table 5. Socio-demographic characteristics of respondents.

\begin{tabular}{lll}
\hline Variable & Frequency & Percentage \\
\hline Age of Respondents & 102 & \\
$21-30$ & 48 & 58.6 \\
$31-40$ & 15 & 27.6 \\
$41-50$ & 9 & 8.6 \\
$51-60$ & & 5.2 \\
Gender & 90 & \\
Male & 84 & 51.7 \\
Female & & 48.3 \\
Marital status & 120 & \\
Single & 54 & 68.9 \\
Married & & 31.1 \\
Educational Level & 9 & \\
Primary & 27 & 5.2 \\
Secondary & 138 & 15.5 \\
Tertiary & & 79.3 \\
Occupation & 12 & 6.9 \\
Teaching staff & 30 & 17.2 \\
Non-teaching & 132 & 75.9 \\
Students & & \\
\hline
\end{tabular}

\subsection{Exposure to Environmental Hazards}

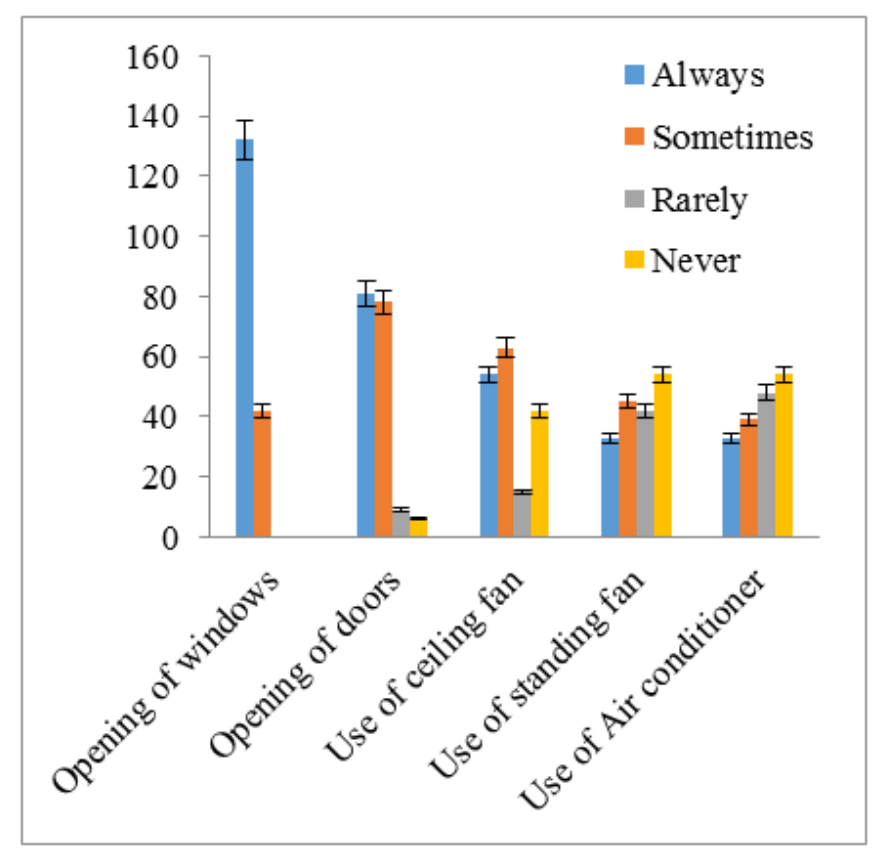

Figure 1. Ventilation methods adopted by participants.

Thirty-eight percent of respondents reported fumes from generator as an environmental hazard they are exposed to in their offices and classrooms. Only $4.0 \%$ of respondent reported non-exposure to hazards in their offices and classrooms. Ventilation methods used by study participants are documented in Figure 1. Majority of respondents always opened their windows and doors to ensure well ventilated indoor environment.

\subsection{Perceived Health Effects}

Reported symptoms of disease among respondents in the last six months prior the study is presented in Table 6 . Half $(50.0 \%)$ of respondents experienced these symptoms while in their offices; $62.0 \%$ of these reported relief from the symptoms after leaving the office environment.

Table 6. Symptoms experienced in the last six months.

\begin{tabular}{ll}
\hline Symptoms & Frequency (\%) \\
\hline Coughing (dry or wet) & $114(65.5)$ \\
Tiredness/fatigue & $141(81.0)$ \\
Wheezing, Sneezing & $153(87.9)$ \\
Eye, nose and throat Irritation & $120(69.0)$ \\
Tightness of chest & $36(20.7)$ \\
Breathing difficulties & $60(34.5)$ \\
Running nose (Catarrh) & $117(67.2)$ \\
Shortness of breath & $45(25.9)$ \\
Blurred vision & $27(15.5)$ \\
Nausea, Dizziness & $72(41.4)$ \\
\hline
\end{tabular}

Multiple responses

\section{Discussion}

The mean morning and afternoon readings for both temperature and relative humidity in all sampled locations exceeded the ASHRAE guideline limits. Abdul-Wahab in his study reported that the most comfortable temperature inside a building is between $20^{\circ} \mathrm{C}$ and $23^{\circ} \mathrm{C}$ in winter and $20-25^{\circ} \mathrm{C}$ in summer with relative humidity of $40-60 \%$. An indoor building temperature above $25^{\circ} \mathrm{C}$ can cause headaches and fatigue while indoor temperature below $18^{\circ} \mathrm{C}$ is likely to cause chills and influenza like symptoms [15].

Studies have shown that high temperatures can cause fatigue, which can then lead to awkward postures such as slouching or slumping in the chair; the cool air blowing directly down can cause cold feet and hands, as well as increased muscle tension and increased risk for tendinitis [16].

Also, high relative humidity may breed mould, rot or pests such as termites or cockroaches [17]. High relative humidity facilitates the growth of different varieties of mould. Moulds can potentially cause rashes, headaches, dizziness, nausea, allergic reactions including hay fever and asthma attacks [18]. At high relative humidity, microorganisms such as fungi and bacteria, can survive on non-living material including dust [19]. High relative humidity (above 70 percent) also tend to favour the survival of viruses composed entirely of nucleic acids and proteins [20].

Findings from this study revealed that the genera of bacteria isolated from the indoor environment included Staphylococcus spp., Bacillus spp., Micrococcus, 
Pseudomonas and Proteus while the isolated fungi specie was Aspergillus. A study conducted in Nigeria by Ana and Umar, [21] in Daycare centres, reported that the genera of bacteria isolated from the indoor environment included Pseudomonas spp., Staphylococcus spp., Bacillus spp.

Elsewhere, most important bacterial strains found in an indoor atmosphere are representatives of the genera Bacillus, Micrococcus, Kocuria and Staphylococcus, Streptomyces albus, Pantoea agglomerans, Pseudomonas chlororaphis, Arthrobacter globiformis, Thermoactinomycetes vulgaris, and Corynebacterium sp. [22]. Hyvärinen et al., [23] in their study reported that the most common fungal genera occurring in indoor environments are Penicillium, Aspergillus, Cladosporium, Alternaria and yeasts.

Numerous studies have proved that exposure to bioaerosols, containing airborne microorganisms and their by-products can result in respiratory disorders and other adverse health effects such as infections, hypersensitivity pneumonitis and toxic reactions [24, 25, 26].

Findings from this study also revealed that majority of the occupants of Ajose building are exposed to a range of pollutants such as generator fumes, dust, excessive heat and chemicals. Most households, commercial and institutional buildings in Nigerian cities operate small capacity fossil fuel electric power generators for electricity supply [27, 28]. Study by Stanley et al., [29], showed that small household generators in Nigeria operate an average of six (6) hours daily, while the average distance of generator away from building was $5.6 \mathrm{~m}$. These alongside poor ventilation have influenced the quality of indoor air in the households [30].

The most predominant ventilation system reported in our study was natural ventilation (opening of doors and windows) method which was grouped as one-sided or cross based on the WHO European standard on mould and dampness in 2009. The natural ventilation system may make it easier for outdoor pollutants to get into the indoor environment thereby further predisposing the occupants to a myriad of infections.

According to Mendell et al., [31] and Fisk [32] building with inadequate ventilation may increase the transmission of infectious respiratory diseases or sinus infections among occupants. There is evidence that low ventilation rates and other building characteristics can lead to increased incidence of respiratory diseases caused by viruses [33]. For best practice Roy [34] recommends that the fresh air ventilation flow rate should be 15 litres per second (lps) per person for an office or for other building rooms that are occupied by people who are performing work tasks.

Poor indoor air quality often manifests itself as complaints and reports of adverse health effects among occupants [35, $36,37]$. Our study reveals that the reported symptoms of disease among respondents in the last six months prior the study include cough, fatigue, wheezing, irritation of the eye, skin and throat, catarrh among others. Studies have also provided us with evidence that indoor environmental quality do influence the prevalence of acute respiratory illnesses, allergies and asthma, and sick building symptoms [16]. Deteriorated indoor environments cause various symptoms, sicknesses, reduced comfort and loss of concentration which may result in inconsistent work, longer breaks, less care of customers, shorter working hours and sick leaves [38]. An increasing number of studies conducted in many countries have demonstrated that the quality of the indoor environment is directly related to health and wellbeing.

A comprehensive literature review by Fisk [39] showed that there is moderate to strong evidence that characteristics of the indoor environment significantly influence rates of a large number of health effects. About $60.0 \%$ of respondents in this study spent more than 8 hours per day in their offices and classroom environment. Redlich et al. [40] found that the duration of time spent working in a building could affect the occurrence of the symptoms of sick building syndrome.

\section{Conclusion}

The indoor air quality and perceived health effects experienced by occupants of an office complex in a typical were assessed in this study. It is evident from this study that the indoor air quality of the sampled locations within Ajose building was poor in relation to acceptable standards since an acceptable indoor air quality is air in which there are no known contaminants at harmful level and with which a substantial majority (i.e. about $80 \%$ ) of the people exposed do not express dissatisfaction. The temperature and relative humidity of the sampled locations were also higher than acceptable limits. All these may influence the prevalence of health symptoms experienced by staff and students working in the Oladele Ajose building.

Routine inspection (air monitoring) of office buildings should be carried out to ensure conformance with stipulated guidelines. Environmental health education on the factors that may contribute to poor indoor air quality and the importance of maintaining a healthful environment should be instituted.

\section{Acknowledgements}

The authors acknowledge the contributions made by the 2012/2013 Master's students of the Department of Environmental Health Sciences, University of Ibadan. We also appreciate the cooperation received from the occupants of the Oladele Ajose Building.

\section{References}

[1] N. Cobanglu and N. Kiper. Bina ici solunan havada tehlikeler. Cocuk Sagligi ve Hastaliklari Dergisi, 2006; 49: 71-75.

[2] E. Gocgeldi, M.E. Berdan, M. Ucar, T. Turker, H. Istanbulluoglu, M. Gulec and M. Hasde. Analysis of children's rooms in terms of microbiological air quality. J. Exp. Integr. Med. 2011; 1: 51-58.

[3] WHO. WHO guidelines for indoor air quality: selected pollutants. The WHO European Centre for Environment and Health, Bonn Office, 2010; 1 - 484 
[4] L.D. Stetzenbach, M.P. Buttner and P. Cruz. Detection and enumeration of airborne contaminants. Curr Biotechnol. 2004; 15: $170-4$

[5] J.A. Hoskins. Health effects due to indoor air pollution. Indoor Built Env. 2007; 12: 427-433.

[6] Li, Y., G.M. Leung, J.W. Tang and X. Yang et al. Role of ventilation in airborne transmission of infectious agents in the built environment - a multidisciplinary systematic review. Indoor Air, 2007; 17: 02-18.

[7] M. Hargreaves, S. Parappukkaran, L. Morawska, J. Hitchins, H. Congrong and D. Gilbert. A pilot investigation into associations between indoor airborne fungal and nonbiological particle concentrations in residential houses in Brisbane. Sci Total Environ. 2003; 312: 89-101.

[8] P. Srikanth, S. Sudharsanam, R. Steinberg. Bioaerosols in indoor environment: Composition, health effects and analysis. Indian J Med Microbiol. 2008; 26: 302-12.

[9] H.A. Ajimotokan, L.A. Oloyede and M.E. Ismail. Influence of Indoor Environment on Health and Productivity. New York Science Journal, 2009; 2(4): 46 - 49.

[10] E.C. Dorgan and B.C. Dorgan. Assessment of Link between Productivity and Indoor Air Quality in Clements-Croome D. The Productive Workplace. London: E\&FN Spon. 2006

[11] P.D. Wyon and P. Wargocki. Indoor Air Quality Effects on Office Work in Clements-Croome D. The Productive Workplace. London: E\&FN Spon. 2006

[12] ASHRAE. Ventilation for Acceptable Indoor Air Quality Standard 62.1. United States of America. 2010

[13] Polish Standard 89/Z-04008/08. Air purity protection. Microbiological testing. Determination number of the fungi in the atmospheric air (imision) with sampling by sedimentation method.

[14] J.G. Holt, N.R. Krieg, P.H. Sneth, J.T. Stanley and S.T. Williams. Bergey's manual of determinative bacteriology, 9th ed. Baltimore, MD: Williams and Wilkins. 1994

[15] Abdul-Wahab. Sick Building Syndrome, Springer-Verlag Berlin Heidelberg, 2011; pg 25-58

[16] J. William and P.E. Fisk. How IEQ Affects Health, Productivity? Member ASHRAE. ASHRAE Journal. 2002

[17] S. Maxwell. "Control moisture to cut odour," The Toronto Star. 2007

[18] Loecher. "'The Surprising truth about mold."Prevention, 2004; $56: 23-24$

[19] H.J. Choa, J. Schwartz, D.K. Milton. Populations and determinants of airborne fungi in large office buildings, Environmental Health Perspectives, 2002; 110: 777-782

[20] P.R. Joel and J.P. Robin. Construction and Characterization of Adenovirus Vectors. Cold Spring Harbor, NY, USA. 2006

[21] G.R.E.E. Ana and Z.O. Umar. Indoor Air Quality and Respiratory Symptoms experienced among under-five children in Daycare centres in Ibadan North Local Government Area, Oyo State, Nigeria. An unpublished Master's dissertation in the Department of Environmental Health Sciences, University of Ibadan, Nigeria. 2013
[22] J. Dutkiewicz, E. Krysinska-Traczyk, C. Skorska et al. Exposure to airborne microorganisms and endotoxin in a potato processing plant. Ann Agric Environ Med. 2002; 9: 225-35.

[23] A. Hyvärinen, T. Meklin, A. Vepsäläinen and A. Nevalainen, A. Fungi and actinobacteria in moisture-damaged building materials- concentrations and diversity. International Biodeterioration and Biodegradation, 2002; 49:27-37

[24] W.E. Horner, A. Helbling, J.E. Salvaggio and S.B. Lehrer. 'Fungal allergens." Clinical Microbiology Reviews, 1995; 8: $161-179$.

[25] R.L. Gorny, T. Roponen, K. Willeke, D. Schmechel, E. Robine, M. Boissier, S.A. Grinshpun. Fungal fragments as indoor air bio-contaminants. Applied Environmental Microbiology, 2002; 68: $3522-321$.

[26] L. Fracchia, S. Pietronave, M. Rinaldi, M.G. Martinotti. The assessment of airborne bacterial contamination in three composting plants revealed site related biological hazard and seasonal variations. Journal of Epidemiology, 2006; 22: 1174 -1182 .

[27] Energy Commission of Nigeria (ECN). 60 Nigerians Now Own Power Generators. Adopted from Vanguard Newspaper, 26th January, 2009. [Online] Available at www.energy.gov.ng.

[28] A.L. Yesufu and G.R. Ana, G.R. Electric Generator Characteristics, Pattern of Use and Non-Auditory Health Effects Experienced by Commercial Workers in Agbowo and Ajibode areas of Ibadan, Nigeria. Review of Global Medicine and Healthcare Research 2012; 3(2): 1-14.

[29] A.M. Stanley, I. Mbamali, I.K. Zubairu, S.A. Bustani, S.S Andrew and I.A. Joshua, I.A. "Electric Power Generator Noise Level Characterization and Impact on Selected Commercial Areas of Zaria and Kaduna Nigeria", International Postgraduate Conference on Infrastructure and Environment, The Hong Kong Polytechnic University, Hong Kong. 2010

[30] E.E. Okafor, A.R. Hassan and A.D. Hassan. Environmental Issues and Corporate Social Responsibility: The Nigeria Experience. J. Hum. Ecol., 2008; 23(2): 101 - 107.

[31] M.J. Mendell, W.J. Fisk and K. Kreiss. Improving the health of workers in indoor environment: priority research needs for the National Occupational Research Agenda, American Journal of Public Health, 2002; 92: 1430-40.

[32] W.J. Fisk. Estimates of potential nationwide productivity and health benefits from better indoor environments: an update. In: Spengler, J., Samet, J.M., McCarthy, J.F. (eds). Indoor Air Quality Handbook, New York: McGraw-Hill, 2000; 4.1-4.36.

[33] W.J. Fisk. 'Estimates of potential nationwide productivity and health benefits from better indoor environments: an update," Indoor Air Quality Handbook.,eds. J. Spengler, J.M. Samet, and J.F. McCarthy, McGraw Hill, New York 2001.

[34] P. Roy. Sick? Sick or Real Sick? Presented at the AIOH J une Sundowner. Chemistry Centre. Curtin University, Bentley, WA 2010 .

[35] D.L. Sudakin. Toxigenic fungi in a water-damaged building: an intervention study. Am. J. Ind. Med. 1998; 34 (2), 183-190.

[36] M. Ahman, A. Lundin, V. Musabasic, E. Soderman. Improved health after intervention in a school with moisture problems. Indoor Air, 2000; 10: 57-62. 
[37] T. Meklin, T. Putus, J. Pekkanen, A. Hyva“ rinen, M.R. Hirvonen, A. Nevalainen. Effects of moisture-damage repairs on microbial exposure and symptoms in schoolchildren. Indoor Air, 2005; 15 (Suppl. 10), 40-47.

[38] M. Tuomainen, J. Smolander, J. Kurnitski, J. Palonen and O. Seppanen. Modelling the cost effects of the indoor environment. Proceedings: Indoor Air 2002 Monterey, California. 814-819.
[39] W.J. Fisk. Estimates of potential nationwide productivity and health benefits from better indoor environments: An update. In J. F. McCarthy (Ed.), Indoor air quality handbook: McGrawHill 1999.

[40] C. Redlich, J. Sparer, M. Cullen. Sick building syndrome. The Lancet 1997; 349:1013-1016. 